\title{
Legal Review of Port Cooperation Agreement: Strength assessment between Law Number 17 of 2008 concerning Ports
}

\author{
Junaedi $^{*}$ \\ *Corresponding Author \\ Junaedi

\section{Article History} \\ Received: 12.01.2020 \\ Accepted: 19.01 .2020 \\ Published: 21.02.2020
}

Government Science, Faculty of Social and Political Sciences, University of Muhammadiyah Makassar, Indonesia

\begin{abstract}
A covenant is an act by which one or more people commit themselves to one or more other people. Agreement is the most important source that gives birth to an engagement. This article discusses the Strength Study between Law Number 17 Year 2008 concerning Ports by looking at the Cooperation Agreement entered into by PT. Pelabuhan Indonesia III (Persero) with PT. Gresik Jasatama in accordance with the Civil Law is as regulated in Article 1338 paragraph (1) of the Civil Code which takes longer than Act No : 17 of 2008 concerning Sailing, this is in accordance with the Lex Posterior Derogat Priori principle. The Ministry of Transportation has the authority and authority at the port as stated in Law No .: 17 of 2008 concerning Shipping and Government Regulation Number 61 concerning Ports so that there is no misunderstanding free from the influence of conflicting interests.
\end{abstract}

Keywords: Legal study, Laws, Agreements, Ports.

\section{INTRODUCTION}

The Port Authority is a government institution in the port area that is very strategic in improving the performance of national ports in improving port performance influenced by factors such as labor problems, lack of port facilities, and lack of security [1]. The Port Authority has a role as a port infrastructure provider and must be able to carry out business principles and must be able to create a conducive business climate for investment in ports [2]. The head of government at the port as regulated in Article 1 paragraph (56) of Law No .: 17 of 2008 concerning Sailing states that: " Syahbandar is a government official at the port appointed by the Minister and has the highest authority to carry out and supervise the fulfillment of statutory provisions to guarantee the safety and security of shipping.".

Port Authority and Port Authority (KSOP) is a government official at the port who is appointed by the Minister and has the highest authority to carry out and supervise the fulfillment of statutory provisions covering regulations, guidance, control, control of port activities and safety, shipping security, and prevention environment (vide article 80 of Law No. 17/2008). The Government Policy at the Port (Syahbandar) is regulated in Article 209, that: In carrying out the functions and duties as referred to in Article 207 and Article 208 in conjunction with article 211 paragraph (1) and paragraph (2) of Law No: 17 of 2008 concerning Shipping implied "That Syahbandar has the authority to coordinate all governmental activities at the port, inspect and store ship documents, documents, and ship reports, issue approval for vessel activities at the port, conduct ship inspections, issue Sailing Permits, inspect ship accidents, hold vessels according to court orders and carry out the sijil Crew "and" Syahbandar have the highest authority to coordinate customs, immigration, quarantine, and other government institution activities". Where the coordination carried out by the Syahbandar as referred to in Article 211 paragraph (1) of Law No .: 17 of 2008 concerning Sailing aims to realize legal certainty (rechtszekerheid, legal certainty) is an important principle in legal action (rechtshandeling) and law enforcement ( hendhaving, uitvoering).

Copyright @ 2020: This is an open-access article distributed under the terms of the Creative Commons Attribution license which permits unrestricted use, distribution, and reproduction in any medium for non commercial use (NonCommercial, or CC-BY-NC) provided the original author and source are credited. 
A covenant is an event where a person promises to another person or where two people promise one another to do something. Under Article 1313 of the Civil Code, an agreement is an act by which one or more persons commit themselves to one or more other people. Agreement is the most important source that gives birth to an engagement. Aside from the agreement, an agreement can arise from the Act [3]. Therefore, when entering into an agreement the parties intentionally commit themselves to the agreement, which means that each party has the right and obligation to obtain and do something with each other $[4,5]$.

In entering into an agreement, the principle of freedom of contract is known, namely that the parties have the right to determine the substance of the agreement. The principle of freedom of contract is regulated in Article 1338 of the Civil Code, which reads: " All treaties made legally apply as a law to those who make them".

\section{Cooperation Agreement made between PT. Pelabuhan Indonesia III (Persero) with PT. Gresik Jasatama is legal according to the law.}

Cooperation Agreement between PT. Pelabuhan Indonesia III (Persero) with PT. Gresik Jasatama No .: 56 / SPP.FA.040 / P.III-6 and No .: 001 / PK.PEL.III / DIR / VIII / 96 dated August 14, 1996, as last updated with the Third Addendum on Cooperation Agreement No .: PJ.09 / 05 / P.III-2005 and Number: 004 / ADD-P.II / DIR-GJ / VIII / GR05 dated July 5, 2005, concerning the Development and Management of Facilities for the Log and Bulk Goods terminal at the Gresiik Port and Concession Agreement between the Tanjung Perak Main Port Authority Office and PT. Pelabuhan Indonesia (III) Persero regarding the Port of Business Services Exploitation Activities undertaken by PT. Pelabuhan Indonesia III (Persero) No .: HK.107 / 01/12 / OP / TPr-15 and No .: HK.0501 / 700 / P.III-2015, dated November 9, 2015. The answer is legal in accordance with Article 1338 paragraph (1) of the Civil Code, which states that: "All agreements (contracts) made legally apply as a law for those who make them".

A profound question arises. Actually, who is more entitled to determine the Work Agreement, the extension or not the renewal of the employment contract that occurs in the Law Territory of the Port of Indonesia. The answer is surely the Ministry of Transportation of the Republic of Indonesia as a Regulator, not the Director of PT. Pelindo III (Persero). (vide article 82 of Law No.:7/ 2008, jo article 2 PP. No .: 64 of 2015). The question arises again "Where is the cooperation agreement of PT. Pelabuhan Indonesia III (Persero) with PT. Gresik Jasatama is this done (locus delicti)? The answer is the Cooperation Agreement between PT. Pelabuhan Indonesia III (Persero) with PT. Gresik Jasatama is carried out within the territory of the authority of the Ministry of Transportation of the Republic of Indonesia (Class II Port of Gresik, East Java).

On the date, month and year of the cooperation agreement of PT. Pelabuhan Indonesia III (Persero) with PT. Gresik Jasatama is this done (tempus delicti)? (1) Cooperation Agreement between PT. Pelabuhan Indonesia III (Persero) with PT. Gresik Jasatama No: 56 / SPP.FA.040 / P.III-6 and No .: 001 / PK.PEL.III / DIR / VIII / 96 dated August 14, 1996 as last renewed with the Third Addendum on Cooperation Agreement No .: PJ .09 / 05 / P.III-2005 and No: 004 / ADD-P.II / DIR-GJ / VIII / GR-05, dated July 5, 2005; (2) Concession Agreement between the Tanjung Perak Main Port Authority Office and PT. Pelabuhan Indonesia III (Persero) regarding Port Service Services Exploitation Activities undertaken by PT. Pelabuhan Indonesia III (Persero) No .: HK.107 / 01/12 / OP / TPr-15 and No: HK.0501 / 700 / P.III2015, dated 9 November 2015.

The answer is the Cooperation Agreement made by PT. Pelabuhan Indonesia III (Persero) with PT. Gresik Jasatama in accordance with the Civil Law is as regulated in Article 1338 paragraph (1) of the Civil Code which takes longer than the Act No :: 17 of 2008 concerning Shipping this is in accordance with the Lex Posterior Derogat Priori principle where The applicable law then invalidates the previous law, insofar as the law regulates the same object.

Let us examine this cooperation agreement in a Cooperation Agreement as regulated in Article 1338 paragraph (1) of the Civil Code, which states that: "All agreements (contracts) made legally apply as a law for those who make it ". But in an Agreement, it must be remembered that there are two factors that must be considered, including the following: (1) Autonomous Factors originating from the parties, namely PT. Pelabuhan Indonesia III (Persero) with PT. Gresik Jasatama for legal certainty from the Ministry of Transportation of the Republic of Indonesia as regulator; (2) Heteronomic factors are factors that originate from outside the parties in determining the binding power of an agreement. This heteronomous factor can be traced to the provisions of Article 1339 and Article 1347 of the Civil Code. Article 1339 of the Civil Code confirms that "An agreement is not only binding for matters that are expressly stated therein, but also for anything that according to the nature of the agreement, is required by propriety, custom or law". Furthermore, in the provisions of Article 1347 of the Civil Code, it is stated that "Matters which are traditionally always agreed, are considered to be secretly included in the agreement, even though they are not explicitly stated". Where the Heteronom Factor is Law No :. 17 of 2008 concerning Shipping Jo Government Regulation No .: 61 of 2009 as amended by Government Regulation. No .: 64 of 2015 concerning Harbor in this case the ex officio is the Ministry of Transportation of the Republic of Indonesia (Dirjen Hublu cq KSOP). 
Based on the two articles, the heteronomous factor to determine the binding power of an agreement consists of the usual terms of an agreement; propriety; habit; and laws [6]. the binding force of an agreement which in principle has work power (streaking) applies only to the competent parties [7].

\section{Terms of the validity of the agreement According to the Civil Code (Civil Code)}

According to the Civil Code (Civil Code) Article 1320, the legal requirements for the agreement are as follows: the legal conditions of the agreement (Subjective Conditions): (1) Agreement of the parties in the agreement, (2) The ability of the parties in the agreement.

Terms of the validity of the agreement (Objective Conditions), (3) A certain thing (4) A halal cause. If an agreement does not meet the subjective conditions, then the agreement can be canceled. Meanwhile, if an agreement does not meet objective conditions, then the agreement is null and void. The objective conditions here (a specific matter and legal reason) are that the Agreement violates Law No. 17/2008 concerning shipping as stated in Article 344, paragraph (1) and paragraph (2), which states that "In when this Law comes into force, the Government, regional government, and State-Owned Enterprises that operate ports continue to carry out business activities at ports based on this Law.

Within a maximum period of 3 (three) years since this Law comes into force, port business activities carried out by the Government, regional governments and State-Owned Enterprises as referred to in paragraph (1) must be adjusted to the provisions as regulated in this Law ". And in Article 345 paragraph (1) and paragraph (2) of Law No .: 17 of 2008 concerning shipping, "states that the Agreement or cooperation within the Work Environment Area between a StateOwned Enterprise that has operated a port business and a third party still valid. However, it should be carefully noted that this article has verses that are interrelated with one another (cannot be cut off) so as to cause misinterpretation of the law which results in the abuse of legal rights and truth (MisbruikVan Recht).

In addition, when this Law comes into force, agreements or cooperation with State-Owned Enterprises with third parties are carried out in accordance with this Law ". Whereas in article 345 paragraph (1) and paragraph (2) of Law No.:17 of 2008 concerning shipping nature is more specific both locus and tempus delictions about Shipping than Article 1338 paragraph (1) of the more general Civil Code, this is in accordance with the principles where the specific law overrides the general law (Lex Specialis Derogat Legi Generali's principle).

With the objective elements not fulfilled by PT. Pelabuhan Indonesia III (Persero) with PT. Gresik Jasatama, a certain thing here is that: (1) PT. Pelindo is not a Regulator but an Operator while the management, the existence of the port is under the authority of the Ministry of Transportation of the Republic of Indonesia, then this cooperation agreement is null and void because it only relies on 1 (one) Law, namely KUHPerda Article 1338 paragraph (1) so that it will prioritize the law resulting in there are many losses compared to administration (Het doorzettenwaardoor veel nadelen in vergelijking met toediening). (2) What is lawful here is that the contract extension is not in accordance with the Shipping Law. (Vide Articles 344 and 345 paragraph (1) and paragraph (2) of the Shipping Law No.17 / 2008). Cooperation between PT. Pelabuhan Indonesia III (Persero) with PT. Gresik Jasatama has strong legal provisions as regulated in Article 1338 paragraph (1) of the Civil Code but cannot be used as a legal umbrella (Umbrella Act), because the Cooperation agreement is not a legal product, as is the Basic Law ( The 1945 Constitution, Laws, Government Regulations, Regulations, Instructions, Presidential Decrees and not also Judicial decisions (MA, MK, and Courts) that have strong legal provisions ", as stipulated in Chapter III Article 7 paragraph (1) of the Act Law Number 12 of 2011 concerning the Types, hierarchy, and content of laws and regulations, which states that the types and hierarchy of statutory regulations consist of the 1945 Constitution of the Republic of Indonesia, Stipulations of the People's Consultative Assembly, Laws / Government Regulations in Lieu of Laws, Government Regulations, Presidential Regulations, Provincial Regional Regulations, and Regency Regulations en / City and Village Head or equivalent. "

Not in accordance with Article 8 paragraph (2) of Law No. 12 of 2011 further stipulates that: "Legislation, as referred to in paragraph (1), is recognized and has binding legal force insofar as it is ordered by higher Regulations or formed based on authority." Regulations established by institutions as referred to in Article 8 paragraph (1) of Law no. 12 of 2011 with the condition "as long as ordered by higher legislation" can be said to be a statutory regulation (on the basis of a delegation).

Not in accordance with Law No .: 17 of 2008 concerning Shipping and Government Regulation Number 61 of 2009 as amended by Government Regulation. No .: 64 of 2015 concerning Harbor is stronger than the Work Agreement made by PT. Pelabuhan Indonesia III (Persero) with PT. Gresik Jasatama which is based on Article 1338 paragraph (1) of the Civil Code, this is in accordance with the principle of the Lex Superior Derogat Principle of Inferiori Legion, where if there are 2 (two) laws that regulate the same object, the higher applicable law is the Law Lower laws are not binding (Vide Article 7 paragraph (1) and Article 8 Paragraph (1) and paragraph (2) of Law No.12 / 2011). PT. Pelabuhan Indonesia III (Persero) and PT. Gresik Jasatama is not a regulator but a Port Business Entity (BUP) which is an operator 
that must submit to the Ministry of Transportation as a regulator based on Law No .: 17 of 2008 concerning Shipping and Government Regulation Number 61 of 2009 as amended by PP. No .: 64 of 2015 concerning Harbor. (Vide Article 92 jo Article 93 of Law No.17 / 2008). Because the concession issue is regulated in Article 82 paragraph (4) and paragraph (5) of the Law. No .: 17 of 2008 concerning Shipping, "it is very clear that the Port Authority is acting as the government representative who carries out the concession granting, not the party given the concession to make granting concessions to another party because there is no concession above the concession.

Contract extension and contract addendum between PT. Pelabuhan Indonesia III (Persero) with PT. Gresik Jasatama although legitimate according to Article 1338 paragraph (1) of the Civil Code but needs to be reviewed because it crashed into a higher, more specific and newer law, namely Law No.:17 of 2008, this is in accordance with Clausula Rebus Sic Stantibus principle that is a condition that eliminates the obligations of each party in an agreement in the event of a "fundamental change of circumstances" or fundamental changes of a state of legislation.

For the problem of land reclamation results of PT. Gresik Jasatama its land management rights should be carried out by the port authority, where the land area belongs to PT. Gresik Jasatama is based on examination results from the BPKP audit team and the regional office BPN. Surabaya is not included in the global concession of the ministry of transportation with PT. Pelindo III (Persero) so that land use cooperation should be carried out with KSOP Gresik (Port authority).

In accordance with the regulations of the Ministry of Transportation to conduct an audit of Pelindo assets where the Territory of PT. Gresik Jasatama is not listed and is not included in the ownership of the official assets of PT. Pelindo III (Persero). While the BPN complies with legislation as a basic guideline in making a certificate of ownership of land (assets) owned by PT. Pelindo III (Persero) without prior seizing with the Ministry of Transportation (KSOP Gresik); according to the regulation of the Ministry of Transportation to conduct Pelindo asset audits where the PT. Gresik Jasatama is not listed and is not included in the ownership of the official assets of PT. Pelindo III (Persero). While the BPN complies with legislation as a basic guideline in making a certificate of ownership of land (assets) owned by PT. Pelindo III (Persero) without prior permission from the Ministry of Transportation (port authority).

For the sake of safety and prioritizing the people's welfare (salus populi suprema lex), and legal certainty, it is better to extend the contract between PT. Pelabuhan Indonesia III (Persero) with PT. Gresik Jasatama and concessions between PT. Pelabuhan Indonesia III (Persero) with the Gresik Port authority reborn again, of course by submitting an application to the Ministry of Transportation of the Republic of Indonesia Cq Director General of Sea Relations of the Ministry of Transportation who has authority at the port, to prevent legal turmoil, prolonged conflict, and conflict between the two legal obligations (Bij botsing van twee rechtsplichten en een rechtsplicht) as well as conflict legal interests and legal obligations (Bijbotsing Van Twee Rechtsbelangen) behind the day. This is in accordance with what Schmidt [8] stated about the Ultra Vires Doctrine which states that the company cannot carry out activities outside the company's control and does not abuse the rights that are considered to occur if someone uses their rights contrary to the purpose of granting that right or contrary to the objectives of the community (misbruik van reht).

If the middle ground is taken based on the Audie Et Alteram Partem Principle, with wise consideration if the agreement between PT. Pelindo III (Persero) with PT. Gresik Jasatama was conducted under the year 2008, then joined PT. Pelindo III (Persero) and vice versa if the agreement made between PT. Pelindo III (Persero) with PT. Gresik Jasatama was carried out above in 2008 , following the port authority (KSOP Gresik).

\section{CONCLUSION}

Thus it can be concluded, that the legal basis used for the validity of the Cooperation Agreement based on Article 1320 jo. Article 1338 paragraph (1) of the Civil Code has set aside two legal interests, namely Law Number 17 of 2008 concerning Shipping in conjunction with PP No .: 61 of 2009 as amended by Government Regulation. No .: 64 of 2015 concerning Seaport and Law No .: 5 of 1999 concerning Prohibition of Monopolistic Practices and Unfair Business Competition (Vijbotsing Van Twee Rechtsbelangen) within the port environment (Vide Law No. No.5/199 Article paragraph (2) ). Because after all the Ministry of Transportation has the authority and authority at the port it is contained in Law No .: 17 of 2008 concerning Shipping and Government Regulation No. 61 concerning Ports so that there is no misunderstanding free from the influence of conflict of interest. For the safety and welfare of the people is the highest law (salus populi suprema lex

\section{REFERENCES}

1. Setiono, B. A. (2010). Analisis Faktor-faktor yang mempengaruhi kinerja pelabuhan. Jurnal Aplikasi Pelayaran dan Kepelabuhanan, 1(1), 39-60.

2. Juhel, M. H. (2001). Globalisation, privatisation and restructuring of ports. International journal of maritime 
economics, 3(2), 139-174.

3. Bukido, R. (2016). Urgensi Perjanjian dalam Lalu Lintas Hubungan Hukum Perdata. Jurnal Ilmiah Al-Syir'ah, 6(1).

4. Solan, L. M. (2007). Contract as Agreement. Notre Dame L. Rev., 83, 353.

5. Marilang, S. H. (2017). Hukum Perikatan: Perikatan yang Lahir Dari Perjanjian. Indonesia Prime.

6. Potoboda, S. (2014). Akibat Hukum Kegagalan Dalam Pemenuhan Kewajiban Kontraktual. LEX ET SOCIETATIS, 2(1).

7. Sonnekus, J. C. (2014). Procurement contracts and underlying principles of the law-no special dispensation for organs of state (part 2-developing the common law, consequences and remedies). Tydskrif vir die Suid-Afrikaanse $\operatorname{Reg}, 2014(3), 536-559$.

8. Schmidt, K. (1984). Ultra-vires-Doktrin: tot oder lebendig?-Bemerkungen zur Organvertretungsmacht. Archiv für die civilistische Praxis, 184(H. 6), 529-540. 